\title{
Life table parameters of the red palm mite Raoiella indica (Acari: Tenuipalpidae) at various temperatures and for sexual and asexual reproduction
}

\author{
E. G. Fidelis ${ }^{1}$ (D) M. A. S. Reis ${ }^{1,2} \cdot$ M. Negrini $^{1,3} \cdot$ D. Navia $^{4}$
}

Received: 7 June 2018 / Accepted: 24 July 2019 / Published online: 30 July 2019

(c) Springer Nature Switzerland AG 2019

\begin{abstract}
The red palm mite, Raoiella indica Hirst, is a threat to coconut, banana and native Arecaceae and Heliconiaceae in Brazil. This mite originated in the Eastern Hemisphere and was first reported in 2004 in the Americas, where the pest is spreading quickly and causing severe damage to its host plants. The objective of this work was to determine the lifehistory parameters of $R$. indica at constant temperatures, estimate its thermal requirements [threshold temperature $(\mathrm{Tb})$ and thermal constant $(\mathrm{K})$ ] and also compare its life table parameters between sexual reproduction and parthenogenesis. The life tables were constructed on leaflets of Adonidia merrillii at 15, 20, 24, 27, 30 and $34{ }^{\circ} \mathrm{C}$ and $65 \% \mathrm{RH}$ and a 12-h photoperiod. The longevity and the number of laid eggs of non-copulated adult females were evaluated at $27{ }^{\circ} \mathrm{C}$. Raoiella indica had complete development, from egg to adult, only at $20,24,27$ and $30{ }^{\circ} \mathrm{C}$. At $15{ }^{\circ} \mathrm{C}$, the eggs did not hatch, and at $34{ }^{\circ} \mathrm{C}$, the mites survived only until the larval stage. For sexual reproduction, the optimal temperature was $27^{\circ} \mathrm{C}$, under which the reproductive parameters were higher. The reproductive parameters for sexual reproduction were higher than those for parthenogenesis. The $\mathrm{Tb}$ was $14.79{ }^{\circ} \mathrm{C}$, and the thermal constant was 208.33 degree days. The life parameters estimated in this study can be used for modelling and predicting the population growth of $R$. indica in the field and consequently for improving their management strategies.
\end{abstract}

Keywords Life history · Invasive pest · Coconut · Modelling distribution · Thermal requirement

\footnotetext{
E. G. Fidelis

elisangela.fidelis@gmail.com; elisangela.fidelis@embrapa.br

1 Embrapa Roraima, Boa Vista, RR 69301-970, Brazil

2 Faculdade Cathedral, Boa Vista, RR 69317807, Brazil

3 Universidade Federal de Roraima (UFRR), Boa Vista, RR 69304-000, Brazil

4 Embrapa Recursos Genéticos e Biotecnologia, Brasília, DF 70770-917, Brazil
} 


\section{Introduction}

The red palm mite, Raoiella indica Hirst (Tenuipalpidae), was introduced in the Americas slightly more than 10 years ago (Flechtmann and Etienne 2004) and has spread quickly in the continent. Originating from the Eastern Hemisphere (Dowling et al. 2012), this mite was reported in the Americas in 2004, on the Caribbean island of Martinica (Flechtmann and Etienne 2004), and rapidly disseminated to other islands (Rodrigues et al. 2007). Approximately, 5 years later it reached the north, south and central mainland (Bowman and Hoy 2012; Carrillo et al. 2011; Kane et al. 2012; Navia et al. 2011; Vásquez et al. 2008).

Numerous colonies can be found on leaves of infested plants, which later become necrotic leading to heavy yield losses (even higher than 70\%), such as reported for coconut production in Caribbean (Roda et al. 2012) and Mexico (Otero-Colina et al. 2016) and coconut and banana in Brazil (Gondim Jr et al. 2012). In the Americas, $R$. indica has not only built large populations and spread quickly but also extended its host range, attacking several exotic or wild palm species (Arecaceae) and plants of various monocotyledons families such as Cannaceae, Cycadaceae, Heliconiaceae, Musaceae, Pandanaceae, Strelitziaceae and Zingiberaceae (Carrillo et al. 2012a; Gondim Jr et al. 2012; Navia et al. 2015; Gómez-Moya et al. 2017).

Notwithstanding the importance of $R$. indica as an invasive pest in the Americas, some primary biological parameters have not been determined. Although some biological studies have been conducted in both the old and the new world, they were conducted under fixed temperatures ranging between 15 and $29{ }^{\circ} \mathrm{C}$ (González-Reyes and Ramos 2010; FloresGalano et al. 2010; Vásquez et al. 2015; Gómez-Moya et al. 2017; Nusantara et al. 2017), thermal requirements have not been determined and a life table was not constructed.

Accurate information on the effects of climatic parameters, especially temperature, on the development and reproduction of $R$. indica is crucial for defining prevention and control measures. Models, including potential effects of climate change scenarios (Navia et al. 2016) based on occurrence reports and biological parameters and population dynamics available in the literature, have already been developed to predict the suitable areas for this mite in South America (Amaro and Morais 2013). These last authors used only presence data, and no physiological requirement was considered. However, the precision of these models could be greatly improved if data on the effect of temperature on $R$. indica life table parameters were available. Some species distribution models, such as Climex, have been built using estimates of the physiological requirements of species (Sutherst 2003).

Estimates of temperature effects on the development rate, survival and reproduction of pests are thus useful to predict the population dynamics in the field and consequently to improve their management strategies (Tanga et al. 2018). The selection of biological control agents is also improved when biological parameters of the target pest are known. In this study, the life-history parameters of $R$. indica, such as development, survival and reproduction, are presented at various constant temperatures and for both sexual and asexual (parthenogenesis) reproduction. 


\section{Materials and methods}

\section{Stock colony}

The females used in this study were from the second generation of $R$. indica colonies collected on leaflets of the Manila palm, Adonidia (=Veitchia) merrillii (Becc.) Becc. (Arecaceae) in Boa Vista, Roraima, Brazil $\left(2^{\circ} 45^{\prime} 27.8^{\prime \prime} \mathrm{N}, 60^{\circ} 43^{\prime} 53.5^{\prime \prime} \mathrm{W}\right)$, and maintained in the laboratory at $27{ }^{\circ} \mathrm{C}, 65 \% \mathrm{RH}$ and a 12 -h photoperiod. The colonies were reared on leaflets of $A$. merrillii (14 cm long), placed into plastic dishes (16 cm diameter) on a moistened polyethylene foam ( $1 \mathrm{~cm}$ thick) with distilled water and bordered with a moistened layer of hydrophilic cotton to keep the turgidity of the leaflet and to prevent the escape of the mites. The foam and cotton were kept continuously wet by the daily addition of distilled water. The leaflets of $A$. merrillii were replaced when they became yellow during the mobile phase of $R$. indica.

\section{Biology of Raoiella indica at various constant temperatures}

The effects of temperature on the life-history parameters of $R$. indica were studied in controlled incubation chambers at six constant temperatures $(15,20,24,27,30$ and $34{ }^{\circ} \mathrm{C}$ ), in the Entomology Laboratory of Embrapa Roraima, Brazil. The relative humidity was maintained at $65 \%$, and there was a 12 -h photoperiod. The temperature and relative humidity inside the incubators were monitored using a digital thermohygrometer and fluctuated by $1{ }^{\circ} \mathrm{C}$ and $10 \%$, respectively.

Each experimental unit consisted of a piece of one A. merrillii leaflet $(5 \mathrm{~cm}$ long) maintained as in mass rearing. The leaflets were bordered with entomological glue to prevent the mites from being trapped in cotton and dying. Five adult females of $R$. indica were transferred to each experimental unit, and after $15 \mathrm{~h}$, the adult female and the excess eggs were removed, leaving only one egg per unit. For each temperature, 60-70 units were established.

The units were observed at 24-h intervals, under a stereomicroscope with $\times 40$ magnification, to determinate the mortality, duration of each stage and the daily fertility of mites until their death. When a female reached the teleiochrysalis stage, one male from the mass rearing was transferred to a new unit and replaced-if necessary-until the female died.

\section{Longevity and reproduction by parthenogenesis reproduction}

To compare the longevity and reproductive parameters of $R$. indica by sexual reproduction and parthenogenesis, 80 moulted adult females from the stock colony that had not copulated were observed at $27{ }^{\circ} \mathrm{C}$ under the same conditions as described above. The eggs laid by the females were also observed for sex determination.

\section{Analysis of life tables}

The analysis of life tables for $R$. indica at various temperatures was performed using standard methods by Southwood (1978) and Maia et al. (2000). Life table parameters, 
such as net productive rate $\left(\mathrm{R}_{0}\right)$, intrinsic rate of natural increase $\left(\mathrm{r}_{\mathrm{m}}\right)$ and mean generation time $(\mathrm{T})$, were estimated.

The duration of each stage and oviposition and pre-oviposition periods at the various temperatures were compared using Kruskal-Wallis $(\alpha=0.05)$. Dunn test was used as post hoc test to determine which temperatures were different from others. Survival and fertility parameters at different temperatures were analysed using one-way ANOVA $(\alpha=0.05)$. If significant differences were detected, then a Tukey HSD test was used. One-way ANOVA was also used to compare the fertility parameters for sexual versus parthenogenesis reproduction at $27^{\circ} \mathrm{C}$.

\section{Thermal requirements}

The threshold temperature $(\mathrm{Tb})$ and thermal constant $(\mathrm{K})$ were calculated by the thermal summation model (Campbell et al. 1974), using the linear relationship between temperature and the rate of development of $R$. indica: $1 / \mathrm{D}=\mathrm{a}+\mathrm{bT}$, where $\mathrm{D}$ is the development time and $\mathrm{T}$ is the ambient temperature $\left({ }^{\circ} \mathrm{C}\right)$. The thermal constant $(\mathrm{K}=1 / \mathrm{b})$ is the number of degree days or heat units above the threshold needed for the species to complete its development.

\section{Results}

Raoiella indica had complete egg-to-adult development only at $20,24,27$ and $30{ }^{\circ} \mathrm{C}$. At $15^{\circ} \mathrm{C}$, the eggs survived a mean of 66.7 days, when they had a normal format and colouration; however, after this period, they became discoloured, and wilted and did not hatch. At $34{ }^{\circ} \mathrm{C}$, the mites survived only until the larval stage (Table 1 ).

There were significant differences between the durations of all life stages and cumulative development (egg to adult) at the various temperatures, and the durations were inversely proportional to temperature. The mean duration of all stages, except that of the egg, was higher at $20^{\circ} \mathrm{C}$. The development times from egg to adult at $20,24,27$ and $30{ }^{\circ} \mathrm{C}$ were 35.8, 24.7, 17.9 and 13.3 days, respectively (Table 1).

The shortest duration of the egg stage was a mean of 3.67 days at $30{ }^{\circ} \mathrm{C}$. The durations of the larval and protonymphal stages were the shortest and similar at 24,27 and $30{ }^{\circ} \mathrm{C}$. The shortest duration of the deutonymph stage was at $30^{\circ} \mathrm{C}$ at 1.67 days. Female longevity was longest at $20^{\circ} \mathrm{C}$ (70.1 days), intermediate at 24 and $27^{\circ} \mathrm{C}$ (29.6 and 24.1 days, respectively), and shortest at $30{ }^{\circ} \mathrm{C}(3.5$ days; Table 1$)$.

The mean preoviposition period ranged from 1.0 day at $30{ }^{\circ} \mathrm{C}$ to 3.5 days at $20{ }^{\circ} \mathrm{C}$. The oviposition period was similar at 20,24 and $27^{\circ} \mathrm{C}$ (13.5, 22.8 and 19.0 days, respectively) and shortest at $30^{\circ} \mathrm{C}$ ( 1 day) (Table 1$)$.

The relation between the development rate and temperature ranging from 15 to $30{ }^{\circ} \mathrm{C}$ was linear $\left(\mathrm{R}^{2}=0.99, \mathrm{P}<0.0001\right)$. The estimated minimum temperature of development (Tb) was $14.79^{\circ} \mathrm{C}$, and the thermal constant (K) 208.33 degree days.

The survival of eggs was similar at the various temperatures $(\mathrm{F}=2.78, \mathrm{P}=0.087)$, except at $15{ }^{\circ} \mathrm{C}$, when all eggs died. Survival rates of mobile stages (larva, protonymph and deutonymph) and of egg-to-adult was higher and similar at 20, 24 and $30{ }^{\circ} \mathrm{C}$ (Table 2).

The reproductive parameters number of eggs/female, net reproductive rate $\left(\mathrm{R}_{0}\right)$ and intrinsic rate of natural increase $\left(\mathrm{r}_{\mathrm{m}}\right)$ were highest at $27{ }^{\circ} \mathrm{C}$ for sexual reproduction (47.02 eggs/female, $R_{0}=24.21$ and $r_{m}=0.13$ ), suggesting that this is the 


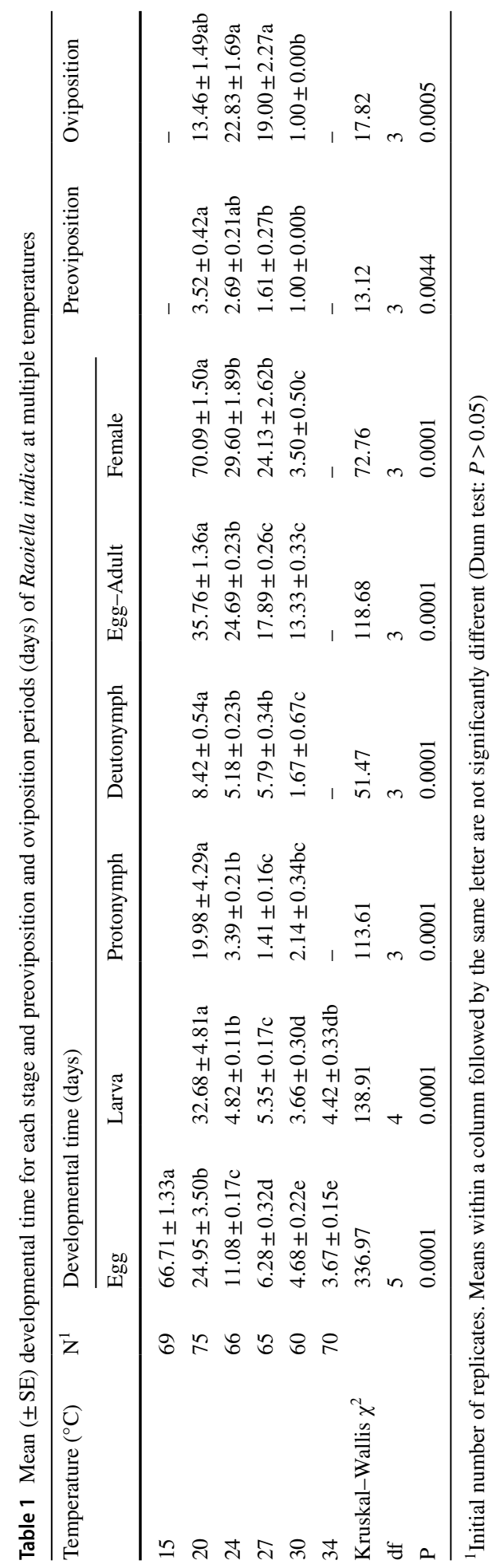


Table 2 Mean ( \pm SE) survivorship (\%) for each stage of Raoiella indica at multiple temperatures

\begin{tabular}{llllll}
\hline $\begin{array}{l}\text { Tempera- } \\
\text { ture }\left({ }^{\circ} \mathrm{C}\right)\end{array}$ & Egg & Larva & Protonymph & Deutonymph & Egg-Adult \\
\hline 15 & 0 & - & - & - & - \\
20 & $87.14 \pm 6.16 \mathrm{a}$ & $66.85 \pm 8.26 \mathrm{~b}$ & $79.49 \pm 5.34 \mathrm{a}$ & $100.00 \pm 0.00 \mathrm{a}$ & $46.90 \pm 9.51 \mathrm{a}$ \\
24 & $93.62 \pm 1.90 \mathrm{a}$ & $98.77 \pm 1.23 \mathrm{a}$ & $91.66 \pm 1.82 \mathrm{a}$ & $93.86 \pm 3.41 \mathrm{a}$ & $81.35 \pm 3.25 \mathrm{a}$ \\
27 & $78.24 \pm 1.70 \mathrm{a}$ & $80.95 \pm 3.06 \mathrm{ab}$ & $94.66 \pm 2.68 \mathrm{a}$ & $91.41 \pm 4.82 \mathrm{a}$ & $54.72 \pm 3.49 \mathrm{a}$ \\
30 & $88.33 \pm 6.01 \mathrm{a}$ & $11.96 \pm 9.18 \mathrm{c}$ & $16.67 \pm 16.67 \mathrm{~b}$ & $66.67 \pm 0.00 \mathrm{~b}$ & $1.11 \pm 1.11 \mathrm{~b}$ \\
34 & $75.00 \pm 5.00 \mathrm{a}$ & 0.0 & - & - & - \\
$\mathrm{F}$ & 2.78 & 34.36 & 14.79 & 8.09 & 14.56 \\
$\mathrm{df}$ & 5,10 & 4,8 & 3,6 & 3,6 & 3,6 \\
$P$ & 0.087 & $<0.0001$ & 0.0035 & 0.016 & 0.0037 \\
\hline
\end{tabular}

Means within a column followed by the same letter are not significantly different (Tukey HSD test: $P>0.05)$

optimal temperature for $R$. indica. The shorter mean generation time (T) was 24.78 and 15.25 days at 27 and $30{ }^{\circ} \mathrm{C}$, respectively. The proportion of females was higher than 0.8 at all the temperatures (Table 3 ).

The survival curve $\left(\mathrm{L}_{\mathrm{x}}\right)$ of $R$. indica at $20{ }^{\circ} \mathrm{C}$ shows a steep decrease at the end of the life cycle. At this temperature, the longest living mite died on day 110. At 24 and $27^{\circ} \mathrm{C}$, the survival curves indicated relatively constant mortality rate throughout the life expectancies. At $30{ }^{\circ} \mathrm{C}$, mortality was high at the beginning of the life cycle, the mites lived a maximum of 17 days (Fig. 1).

Peak oviposition rate of $R$. indica was observed at $27{ }^{\circ} \mathrm{C}$ on days $27-30$, with 4.1 eggs/female/day; eggs were laid until day 64. At $24{ }^{\circ} \mathrm{C}$, the maximum rate of oviposition was on day $32, \mathrm{~m}_{\mathrm{x}}=3.4 \mathrm{eggs} / \mathrm{female} / \mathrm{day}$, and eggs were laid until day 70 . At $20^{\circ} \mathrm{C}$, the highest fecundity was 0.56 eggs/female/day on day 41 , and eggs were laid until day 75. At $30{ }^{\circ} \mathrm{C}$, peak fecundity was low at $0.67 \mathrm{eggs} / \mathrm{female} / \mathrm{day}$, and eggs were laid on only 3 days, from days 13 to 16 (Fig. 1).

Table 3 Mean $( \pm S E)$ number of eggs/female, net reproductive rate $\left(R_{0}\right)$, intrinsic rate of increase $\left(r_{m}\right)$, generation time ( $\mathrm{T}$ ) and sex ratio (proportion daughters) of Raoiella indica at multiple temperatures

\begin{tabular}{llllll}
\hline $\begin{array}{l}\text { Temperature } \\
\left({ }^{\circ} \mathrm{C}\right)\end{array}$ & Egg/female & $\mathrm{R}_{0}$ & $\mathrm{r}_{\mathrm{m}}$ & $\mathrm{T}$ & Sex ratio \\
\hline 20 & $11.75 \pm 1.76 \mathrm{bc}$ & $5.00 \pm 0.95 \mathrm{~b}$ & $0.03 \pm 0.00 \mathrm{c}$ & $46.25 \pm 3.04 \mathrm{a}$ & 0.92 \\
24 & $21.85 \pm 3.41 \mathrm{~b}$ & $17.99 \pm 3.42 \mathrm{ab}$ & $0.07 \pm 0.00 \mathrm{~b}$ & $39.98 \pm 1.81 \mathrm{a}$ & 0.96 \\
27 & $47.02 \pm 3.85 \mathrm{a}$ & $24.21 \pm 4.36 \mathrm{a}$ & $0.13 \pm 0.01 \mathrm{a}$ & $24.78 \pm 0.22 \mathrm{~b}$ & 0.84 \\
30 & $0.07 \pm 0.07 \mathrm{c}$ & $0.07 \pm 0.07 \mathrm{~b}$ & $-0.04 \pm 0.04 \mathrm{~d}$ & $15.25 \pm 0.0 \mathrm{~b}$ & 1 \\
$\mathrm{~F}$ & 29.54 & 8.38 & 173.85 & 30.62 & 3,6 \\
$\mathrm{df}$ & 3,6 & 3,6 & 3,6 & 0.0005 & \\
$P$ & 0.0005 & 0.01 & $<0.0001$ & & \\
\hline
\end{tabular}

Means within a column followed by the same letter are not significantly different (Tukey HSD test: $P>0.05)$ 

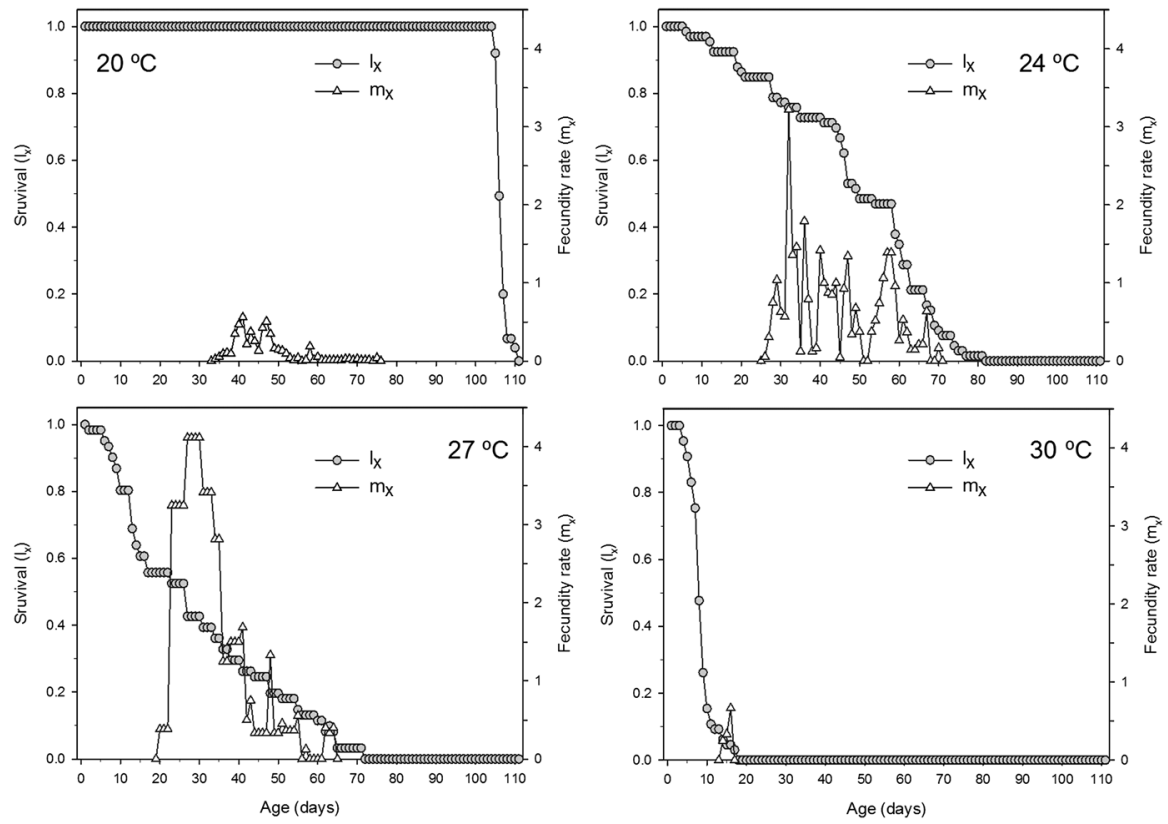

Fig. 1 Survival $\left(1_{\mathrm{x}}\right)$ and fecundity rate $\left(\mathrm{m}_{\mathrm{x}}\right)$ of Raoiella indica at $20,24,27$ and $30^{\circ} \mathrm{C}$

The reproductive parameters estimated for $R$. indica (no. eggs/female, $\mathrm{R}_{0}$ and $\mathrm{r}_{\mathrm{m}}$ ) at $27{ }^{\circ} \mathrm{C}$ for sexually reproducing females were significantly higher than those for parthenogenetic females. The generation time $(\mathrm{T})$, female longevity and preoviposition period were low for sexual reproduction. The oviposition periods did not differ (Table 4). The eggs laid by virgin females resulted in males, which confirms the arrhenotokous parthenogenesis of $R$. indica.

\section{Discussion}

The reproductive parameters of $R$. indica at $27{ }^{\circ} \mathrm{C}$ obtained in this study were generally higher than those reported by other authors who carried out experiments at similar temperatures. At $27{ }^{\circ} \mathrm{C}$, for sexual reproduction, the mean number of eggs/female was 47 , which was $3 \times$ higher than the 14 eggs/female at $26-28{ }^{\circ} \mathrm{C}$ observed by Nusantara et al. (2017) or 12.6 eggs/female at $26.3 \pm 1.3{ }^{\circ} \mathrm{C}$ (Gonzalez-Reyes and Ramos 2010; Lima et al. 2011). These laboratory studies all had detached coconut leaflets.

Even when the biology of $R$. indica was studied on $A$. merrillii, the net reproductive rate $\left(\mathrm{R}_{0}\right)$ estimated at $27{ }^{\circ} \mathrm{C}(24.21)$ for sexual reproduction was $13.8 \times$ higher than that estimated at $29 \pm 0.5^{\circ} \mathrm{C}$ by Vásquez et al. $(2015)\left(\mathrm{R}_{0}=1.76\right)$ and $3 \times$ higher than that estimated at $30 \pm 4.61{ }^{\circ} \mathrm{C}$ by Gómez-Moya et al. (2017) $\left(\mathrm{R}_{0}=8.1\right)$. These authors performed their studies on plants in screenhouses, and they suggested the development of $R$. indica is negatively affected when it is fed with detached leaves as they may close their stomata locally where this mite feeds (Beard et al. 2012). At least for A. merrillii, leaf detachment did not affect the performance of $R$. indica probably because the detached leaves do not 


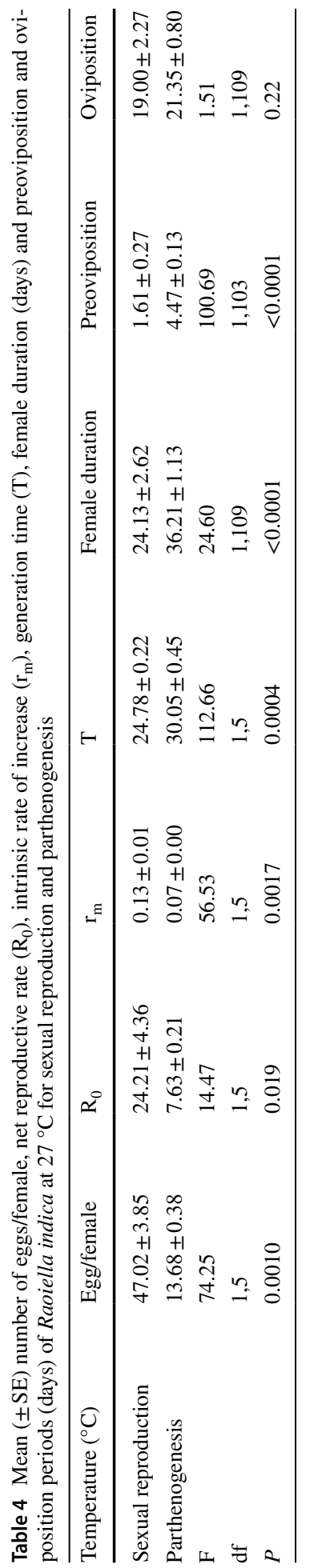


close their stomata (E.G. Fidelis, personal observation), and they keep their physiological characteristics. In fact, during the experiment, the leaflets kept green and turgid until 68 days at $15{ }^{\circ} \mathrm{C}$ when we observed the eggs, 30 days at $20{ }^{\circ} \mathrm{C}$ and 7 days at $34{ }^{\circ} \mathrm{C}$, showing that the rearing units with $A$. merrillii leaflets were adequate for $R$. indica. This result can explain the lower reproductive rates observed in studies with coconut leaflets at similar temperatures (Nusantara et al. 2017; Gonzalez-Reyes and Ramos 2010; Lima et al. 2011; Vásquez et al. 2015). In the field, coconut is considered the preferential host of $R$. indica, when this mite reaches high population levels (Gondim Jr. et al. 2012; Kane et al. 2012; Otero-Colina et al. 2016). However, we carried out previous experiments using detached leaflets of coconut and observed that the coconuts dried and became brown after 3-4 days; for this reason, the biology of $R$. indica was studied on A. merrillii.

The shorter reproductive rates of $R$. indica observed by Gómez-Moya et al. (2017), even on plants, can be related to the high mean temperature inside the screenhouse $\left(30 \pm 4.6^{\circ} \mathrm{C}\right)$. At a constant $30{ }^{\circ} \mathrm{C}$, we observed that $R$. indica had low survival and reproductive rates. The temperature inside the screenhouse was approximately $3{ }^{\circ} \mathrm{C}$ higher than the average temperature of $27{ }^{\circ} \mathrm{C}$ in of Boa Vista, Roraima, Brazil (INMET 2018), where this mite reaches a high population density in the field (Gondim Jr et al. 2012).

The development time of $R$. indica at $27{ }^{\circ} \mathrm{C}$ was similar to that in other studies. As in this work, at $24-29{ }^{\circ} \mathrm{C}$ the mite takes approximately 18-30 days to complete egg to adult development (Nusantara et al. 2017; Gonzalez-Reyes and Ramos 2010; Lima et al. 2011; Vásquez et al. 2015). The minimum temperature of development (Tb) of $14.8^{\circ} \mathrm{C}$ estimated for $R$. indica in this study indicates that this species can establish in regions with mild temperatures, as southern Brazil. The mean minimum temperature for the northern region of Paraná State, for instance, where $R$. indica is present (Hata et al. 2017), is $17.5^{\circ} \mathrm{C}$, so this mite can develop well even during the coldest part of the year.

These thresholds can improve the models of potential distributions estimated by Amaro and Morais (2013) and Navia et al. (2016). According to these authors, the majority of the area in the south of Brazil has climatic conditions unfavourable for $R$. indica. The Maxent model calculated by Amaro and Morais (2013) showed that this entire region, except the coasts of Paraná and Santa Catarina, has very low suitability for $R$. indica. Navia et al. (2016) predicted the southern region is unfavourable during most of the year, except for the extreme north of Paraná from September to March and for western Rio Grande do Sul from November to February under the A2 gas emission scenarios from the Intergovernmental Panel on Climate Change. Recently this mite was reported in the west of São Paulo (southeastern Brazil) (Oliveira et al. 2016), northern Paraná (southern Brazil) (Hata et al. 2017), Minas Gerais, Goiás, Distrito Federal and the centre of Bahia (Melo et al. 2018), all regions that had been predicted to have very low suitability for the establishment of $R$. indica according to these models.

The temperature ranges and levels of favourability proposed by Navia et al. (2016) should be changed, according to these results. For example, the levels of favourability for the range of $35<\mathrm{T} \leq 40{ }^{\circ} \mathrm{C}$ should be unfavourable for all relative humidity ranges. A new range between 15 and $20^{\circ} \mathrm{C}$ should be proposed for low favourability and another from 10 to $15{ }^{\circ} \mathrm{C}$ for unfavourability. The life table parameters and thermal requirements estimated in this study for $R$. indica will be useful to improve the Maxent model. Including information about physiological requirements can improve the reliability of $R$. indica distribution models (Ebeling et al. 2008; Elith et al. 2010, Prasad et al. 2012), also for other countries in South America where their host plants have socioeconomic importance.

According to our results, $R$. indica can develop and has high reproductive rates at low temperatures $\left(\mathrm{Tb}=14.79{ }^{\circ} \mathrm{C}\right)$ and relative humidity (ca. 65\%). It can be a challenge for the 
implementation of biological control programmes, mainly using the most important natural enemy of $R$. indica, Amblyseius largoensis (Muma) (Acari: Phytoseiidae) (Carrillo et al. 2012b; Gondim Jr et al. 2012; Moraes et al. 2012; Morais et al. 2016). Temperature would not be a limiting factor for this predator to become established as its minimum temperature for development $(\mathrm{Tb})$ of $13.5{ }^{\circ} \mathrm{C}$ is similar to that of $R$. indica (Galvão et al. 2007). This predator does not develop at relative humidity below 72\% (Gómez-Moya et al. 2018); therefore, biological control using this natural enemy can be limited during the dry season and in drier regions, such as some parts of northeastern Brazil.

Knowing life table parameters at multiple temperatures and the thermal requirements of $R$. indica can be useful for predicting population growth in the field and consequently for implementing control measures (Fand et al. 2014). However, the model of prediction could further be improved if the effects of rain, relative humidity and fluctuating temperatures were known. The life-history parameters presented here were obtained at constant temperatures, under laboratory conditions; however, in the field, the temperature variation is high and this mite may present fluctuating development and reproductive rates. Therefore, the models of potential distributions for $R$. indica should consider, besides the thermal requirements and presence data, the population dynamics of the mite in the field. Some species distribution models, such as Climex, consider the spatio-temporal dynamics of species in the field and seasonal patterns of favourable climatic conditions and, therefore, produce more accurate models (Silva et al. 2017).

This study is the first to estimate biological parameters for $R$. indica under parthenogenetic reproduction. This species can reproduce by arrhenotokous parthenogenesis, and unfertilized eggs develop into haploid males (Nagesha Chandra and Channa Basavanna 1984). This reproduction strategy enables this mite to easily colonize new areas, e.g. by human dispersion (via infested material), including over long distances or by wind.

Acknowledgements This work was supported by Brazilian Agricultural Research Corporation (Embrapa) (Grant No. 03.11.01.015.00.00) and the National Council for Scientific and Technological Development (CNPq) (Grant No. 473262/2011-8).

\section{References}

Amaro G, Morais EGF (2013) Potential geographical distribution of the red palm mite in South America. Exp Appl Acarol 60:357-365

Beard JJ, Ochoa R, Bauchan GR, Welbourn WC, Pooley C, Dowling APG (2012) External mouthpart morphology in the Tenuipalpidae (Tetranychoidea): Raoiella a case study. Exp Appl Acarol 57:227-255

Bowman HM, Hoy MA (2012) Molecular discrimination of phytoseiids associated with the red palm mite Raoiella indica (Acari: Tenuipalpidae) from Mauritius and South Florida. Exp Appl Acarol 57:395-407

Campbell A, Frazer BD, Gilbert N, Gutierrez AP, Markauer M (1974) Temperature requirements of some aphids and their parasites. J Appl Ecol 11:431-438

Carrillo D, Navia D, Ferragut F, Pena JE (2011) First report of Raoiella indica (Acari: Tenuipalpidae) in Colombia. Fla Entomol 94:370

Carrillo D, Amalin D, Hosein F, Roda A, Duncan RE, Peña JE (2012a) Host plant range of Raoiella indica Hirst (Acari: Tenuipalpidae) in areas of invasion of the new world. Exp Appl Acarol 57:271-289

Carrillo D, Frank JH, Rodrigues JCV, Peña JEP (2012b) A review of the natural enemies of the red palm mite, Raoiella indica (Acari: Tenuipalpidae). Exp Appl Acarol 57(3-4):347-360

Chandra BKN, Basavanna GPC (1984) Development and ecology of Raoiella indica Hirst (Acari: Tenuipalpidae) on coconut. In: Griffiths DA, Bowman CE (eds) Acarol, vol 6. Wiley, Chichester, pp 785-790

Dowling APG, Ochoa R, Beard JJ, Welbourn WC, Ueckermann EA (2012) Phylogenetic investigation of the genus Raoiella (Prostigmata: Tenuipalpidae): diversity, distribution, and world invasions. Exp Appl Acarol 57:257-269 
Ebeling SK, Welk E, Auge H, Bruelheide H (2008) Predicting the spread of an invasive plant: combining experiments and ecological niche model. Ecography 31:709-719

Elith J, Kearney M, Phillips S (2010) The art of modelling range-shifting species. Methods Ecol Evol $1: 330-342$

Fand BB, Tonnang HEZ, Kumar M, Kamble AL, Bal SK (2014) A temperature-based phenology model for predicting development, survival and population growth potential of the mealybug, Phenacoccus solenopsis (Hemiptera: Pseudococcidae). Crop Prot 55:98-108

Flechtmann CHW, Etienne J (2004) The red palm mite, Raoiella indica Hirst, a threat to palms in the Americas (Acari: Prostigmata: Tenuipalpidae). Sys Appl Acarol 9:109-110

Flores-Galano G, Montoya A, Rodriguez H (2010) Biologia de Raoiella indica Hirst (Acari: Tenuipalpidae) sobre Areca catechu L. Rev Protección Veg 25:11-16

Galvão AS, Gondim JRMGC, Moraes GJ, Oliveira JV (2007) Biologia de Amblyseius largoensis (Muma) (Acari: Phytoseiidae), um potencial predador de Aceria guerreronis Keifer (Acari: Eriophyidae) em coqueiro. Neotrop Entomol 36(3):465-470

Gómez-Moya CA, Lima TPS, Morais EGF, Gondim MGC Jr, Moraes GJ (2017) Hosts of Raoiella indica Hirst (Acari: Tenuipalpidae) Native to the Brazilian Amazon. J Agric Sci 9(4):86-94

Gómez-Moya CA, Gondim MGC Jr, Moraes GJ, Morais EGF (2018) Effect of relative humidity on the biology of the predatory mite Amblyseius largoensis (Acari: Phytoseiidae). Int J Acarol. https://doi. org/10.1080/01647954.2018.1530300

Gondim MGC Jr, Castro TMMG, Marsaro AL, Navia D, Melo JWS, Demite PR, Moraes GJ (2012) Can the red palm mite threaten the Amazon vegetation? Syst Biodivers 10:527-535

González-Reyes M, Ramos M (2010) Plantas hospedantes de Raoiella indica Hirst (Acari: Tenuipalpidae) en el municipio de Santiago de Cuba. Rev Protección Veg 25:7-10

Hata FT, Silva JEP, Ventura MU, Pasini A, Roggia S (2017) First report of Raoiella indica (Hirst) (Acari: Tenuipalpidae) in southern Brazil. Neotrop Entomol 46:356-359

INMET-Instituto Nacional de Meteorologia (2018) Dados Meteorológicos para Ensino e Pesquisa (BDMEP). www.inmet.gov.br/projetos/rede/pesquisa. Accessed 07 June 2018

Kane EC, Ochoa R, Mathurin G, Erbe EF, Beard JJ (2012) Raoiella indica (Acari: Tenuipalpidae): an exploding mite pest in the neotropics. Exp Appl Acarol 57:215-225

Lima MR, Rodríguez H, González A, González M (2011) Management strategy of Raoiella indica Hirst (Acari: Tenuipalpidae) in Cuba. Zoosymposia 6:152-159

Maia AHN, Luiz AJB, Campanhola C (2000) Statistical inference on associated fertility life table parameters using Jackknife technique: computational aspects. J Econ Entomol 93:511-518

Melo JW, Navia D, Mendes JA, Filgueiras RMC, Teodoro AV, Ferreira JMS, Guzzo EC, Souza IV, Mendonça RS, Calvet ÉC, Paz Neto AA, Gondim MGC, Morais Fidelis EG, Godoy MS, Santos JR, Silva R, Silva VB, Norte RF, Oliva AB, Domingos C (2018) The invasive red palm mite, Raoiella indica Hirst (Acari: Tenuipalpidae), in Brazil: range extension and arrival into the most threatened area, the Northeast Region. Int J Acarol 44:4-5

Moraes GJ, Castro TMMG, Kreiter S, Quilici S, Gondim MGC Jr, Sá LAN (2012) Search for natural enemies of Raoiella indica Hirst in Réunion Island (Indian Ocean). Acarologia 52:129-134

Morais EGF, Oliveira JS, Gondim MGC Jr, Moraes GJ (2016) Amblyseius largoensis in controlling red palm mite under semi-field conditions. Pesq Agropec Bras 51(5):671-675

Navia D, Marsaro AL Jr, da Silva FR, Gondim MGC Jr, de Moraes GJ (2011) First report of the red palm mite, Raoiella indica Hirst (Acari: Tenuipalpidae), in Brazil. Neotrop Entomol 40:409-411

Navia D, Morais EGF, Mendoça RS, Gondim MGC Jr (2015) Ácaro vermelho-das-palmeiras, Raoiella indica Hirst. In: Vilela EF, Zucchi RA (eds) Pragas introduzidas no Brasil: Insetos e ácaros. ESALQ/USP, Piracicaba, pp 418-452

Navia D, Hamada E, Gondim MGC Jr, Benito NP (2016) Spatial forecasting of red palm mite in Brazil under current and future climate change scenarios. Pesq Agropec Bras 51(5):586-598

Nusantara A, Trisyono YA, Suputa Martono E (2017) Biology of Red Palm Mite, Raoiella indica, on different coconut varieties. Jurnal Perlindungan Tanaman Indonesia 21(1):23-29

Oliveira DC, Prado EP, Moraes GJ, Morais EGF, Chagas EA, Gondim MGC Jr, Navia D (2016) First report of Raoiella indica (Acari: Tenuipalpidae) in southeastern Brazil. Fla Entomol 99:123-125

Otero-Colina G, González-Gómez R, Martínez-Bolaños L, Otero-Prevost LG, López-Buenfil JA, Escobedo-Graciamedrano RM (2016) Infestation of Raoiella indica Hirst (Trombidiformes: Tenuipalpidae) on host plants of high socio-economic importance for tropical America. Neotrop Entomol 45:300-309

Prasad YG, Prabhakar M, Sreedevi G, Ramachandra Rao G, Venkateswarlu B (2012) Effect of temperature on development, survival and reproduction of the mealybug, Phenacoccus solenopsis Tinsley (Hemiptera: Pseudococcidae) on cotton. Crop Prot 39:81-88 
Roda A, Nachman G, Hosein F, Rodrigues JC, Peña JE (2012) Spatial distributions of the red palm mite, Raoiella indica (Acari: Tenuipalpidae) on coconut and their implications for development of efficient sampling plans. Exp Appl Acarol 57(3-4):291-308

Rodrigues JCV, Ochoa R, Kane EC (2007) First report of Raoiella indica Hirst (Acari: Tenuipalpidae) and its damage to coconut palms in Puerto Rico and Culebra Island. Int J Acarol 33(1):3-5

Silva RS, Kumar L, Shabani F, Silva EM, Galdino TVS, Picanço MC (2017) Spatio-temporal dynamic climate model for Neoleucinodes elegantalis using CLIMEX. Int J Biometeorol 61(5):785-795

Southwood TRE (1978) Ecological methods, with particular reference to the study of insect populations, 2nd edn. Chapman and Hall, London, p 524

Sutherst RW (2003) Prediction of species geographical ranges. J Biogeogr 30:805-816

Tanga CM, Khamis FM, Tonnang HEZ, Rwomushana I, Mosomtai G, Mohamed SA, Ekesi S (2018) Risk assessment and spread of the potentially invasive Ceratitis rosa Karsch and Ceratitis quilicii De Meyer, Mwatawala \& Virgilio sp. Nov. using life-cycle simulation models: implications for phytosanitary measures and management. PLoS ONE 5:1-32

Vásquez C, Quirós MG, Aponte O, Sandoval DMF (2008) First report of Raoiella indica Hirst (Acari: Tenuipalpidae) in South America. Neotrop Entomol 37:739-740

Vásquez C, Colmenárez Y, Moraes GJ (2015) Life cycle of Raoiella indica (Acari: Tenuipalpidae) on ornamental plants, mostly Arecaceae. Exp Appl Acarol 65:227-235

Publisher's Note Springer Nature remains neutral with regard to jurisdictional claims in published maps and institutional affiliations. 